Ten. Stands in two areas in the Rhodope mountains of Xanthi region

\title{
Structure and development patterns analysis of Fagus sylvatica s.l.- Quercus dalechampii Ten. stands in two areas in the Rhodope mountains of Xanthi region
}

\author{
MILIOS, E.* \& SMIRIS, P.** \\ * Demokretos University of Thrace, Department of Forestry and Management of the \\ Environment and Natural Resources, Pandazidou 149, 68200 Orestiada, Greece \\ ** Laboratory of Silviculture, School of Forestry \& Natural Environment, Aristotle University of \\ Thessaloniki, 54006 Thessaloniki, Greece
}

\begin{abstract}
This study was conducted in Fagus sylvatica-Quercus dalechampii stands in two areas in the Rhodope mountains of Xanthi. In order to analyse the structure and the development patterns of our stands, 23 plots were established, increment cores were taken, and stem analysis was conducted in 2 couples of dominant (competitive) beech and oak trees. The main results of this research indicate that a) In the mountainous part of the study area, natural and anthropogenic disturbances form the initiation, development and structure of beech-oak stands. However the fact that a number of oak trees survived after the disturbance in combination with landscape topography, which inhibited the dispersion of pine seeds, the species biology and the local climate, which is warmer than that of adjacent areas, influenced the succession pathways in the area and allowed oak to act as a pioneer species. b) Even though only one of the two structural types, found in the submountainous part of the study area, was initiated by (anthropogenic) disturbances, the structure and composition of both structural types stands were and still are formed by illegal cuttings in which the oak wood is preferred. c) In both competing couples, the beech trees, after the first 80-85 years of their life, showed by far higher volume growth rates than the adjacent competitive oak trees which, in combination with the trees height growth patterns, implies, that in the future, a total domination of beech trees (in the two couples) will be observed. d) Forest practice must preserve the mixture of beech and oak in the mountainous part of the study area and enhance the presence of oak component in the submountainous part of the study area, in order to maintain the diversity of these stands, to avoid the disadvantages of a homogenous forest and to mediate an orderly transition of community types, if the predicted increase in the average global temperatures comes true.
\end{abstract}

Key words: Mixed stands, structure, disturbances, development patterns, Fagus sylvatica, Quercus dalechampii, growth, succession. 


\section{Introduction}

Descriptive ecology and in particular descriptive forest ecology provide descriptions and information about the forest structures (Smith 1992). The question is, how do these structures develop and change over time.

Understanding forest stand dynamics and stand development pathways has many applications in forest practice. It contributes, through the prediction of future stand structures and development, to achievement of management objectives, reducing silvicultural manipulations costs and increasing the productivity of forest ecosystems (Oliver kal Larson 1996, Tsitsoni 1997).

In the present study, the main objectives are: a) to determine the origin and what age, diameter and height structures occur in Fagus sylvatica-Quercus dalechampii stands in two areas in the Rhodope mountains (region of Xanthi), b) to analyse their development patterns, c) to reconstruct growth rates of adjacent individual dominant $Q$. dalechampii and $F$. sylvatica (competitive) trees and d) to use this information to suggest silvicultural alternatives for the management of these stands.

\section{Study area}

The central Rhodope mountains, in the region of Xanthi which lies in North-east Greece, is the total study area. This study area is divided in two parts (areas) according to the elevations our mixed stands appear.

In the first part (mountainous part), which lies at the north-west of Xanthi, beech-oak stands are located at elevations from 1150 to $1260 \mathrm{~m}$. The climate is humid with harsh winters, the yearly precipitation averages $980 \mathrm{~mm}$, and the mean annual temperature is $8.0^{\circ} \mathrm{C}$ (Tsiontis and Elias 1996a). During the last decades of the nineteenth century and the first decades of the twentieth century, many flocks of sheep, goats and horses were grazing in the area. In fact, shepherds used to burn large areas in autumn in order to have fresh grass in summer. During these decades people fled the area many times due to war and other events. For more details see Milios (2000a).

In the second part (submountainous part), which lies at the north-east of Xanthi, beech-oak stands are located at elevations from 580 to $750 \mathrm{~m}$. The area has been inhabited since the ancient times. The climate is humid with harsh winters, the yearly precipitation averages 872 $\mathrm{mm}$, and the mean annual temperature is $11.7^{\circ} \mathrm{C}$ (Tsiontis and Elias 1996b).

Geologically, the total study area belongs to Rhodope massif, and the dominant rocks are gneiss, granodiorite, rhyolite, granite, amphibolite (Dimadis and Zachos 1986).

\section{Research method}

In order to study stands structure, 23 representative plots of $500 \mathrm{~m}^{2}(20 \mathrm{~m} \times 25 \mathrm{~m})$ were randomly established. These plots were graded in structural types. 
Ten. Stands in two areas in the Rhodope mountains of Xanthi region

These plots were also graded in types according to their site characteristics. Site type $A$ represents the good site qualities, site type B represents the medium and the C site type represents the bad site qualities. This distinction was made using a combination of several methods such as: the height of the predominant trees in each sample plot ( 5 trees in a plot of $500 \mathrm{~m}^{2}$ ) in relation to their age, the location of the plot on the slope, the shape of the terrain (concave or convex), the slope steepness, the slope exposure (northern, eastern etc.) and the soil depth (Husch et al. 1982, Papamichos 1985, Dafis 1986, Matis 1989, Zingg 1984, Philip 1994, Smith et al. 1997).

For every sample plot the following data were recorded: a) diameter in $\mathrm{cm}$, for trees with a diameter of over $4 \mathrm{~cm}$ (breast height), and b) height in meters. In each plot, increment cores for all species were taken (at a height of $1.3 \mathrm{~m}$ ) in the main diameter classes.

Stem analysis was conducted in 2 couples of dominant (competitive) trees in two structural types. Each couple consists of a dominant oak and an adjacent dominant beech tree. These trees were competitors, they had almost the same height and their crowns were touching each other. From each tree, cross-sectional discs were cut and removed from a $\mathbf{0 . 3} \mathbf{~ m}$ level, breast height, $3.30 \mathrm{~m}$ level and at a 3 meter intervals up to the bole. The last disc was collected from the $5 \mathrm{~cm}$-bole diameter. These discs were taken to the Forestry laboratory in order to measure the rings' width with the ADDO instrument (Smiris 1991, Smiris et al. 1998). In stem analysis the mathematics formulas of Regent instruments in Xlstem V1.1 were used (Fortin and Labranche 1996).

Some stands and study area characteristics, as the stands structure and development patterns, the age of trees (increment cores from trees in the main diameter classes), the area which is occupied by each of the structural types, their distribution in the landscape and the history of the area (social-economic conditions, population removals and land use history) gave information about the origin of the different st. types and the factors which caused the stands initiating disturbances (where they occurred).

Finally, in order to have an indicative picture of our stands soil, a soil profile of a representative site was taken in 5 plots (at least one plot for each st. type) and soil samples were analysed (Alifragis and Papamichos 1995) in the laboratory.

\section{Results}

\subsection{Soil}

In table 1, soil analysis data of two representative soil profiles (one for each part of the study area) are given.

The forest soils are acid brown forest soils (Dystric Cambisoils). 
Table 1. Soil analysis data

\begin{tabular}{|c|c|c|c|c|c|c|c|c|c|c|}
\hline $\begin{array}{c}\text { Soil } \\
\text { profile }\end{array}$ & $\begin{array}{c}\text { Hori } \\
\text { zon }\end{array}$ & $\begin{array}{c}\text { Depth } \\
\mathrm{Cm}\end{array}$ & $\begin{array}{c}\text { Org. } \\
\text { mat. \% }\end{array}$ & $\begin{array}{c}\text { Sand } \\
\%\end{array}$ & $\begin{array}{c}\text { Silt } \\
\%\end{array}$ & $\begin{array}{c}\text { Clay } \\
\%\end{array}$ & $\begin{array}{c}\text { Soil } \\
\text { designation }\end{array}$ & $\mathrm{N} \%$ & $\mathrm{pH}$ & $\begin{array}{c}\text { Site } \\
\text { type }\end{array}$ \\
\hline & $\mathrm{A} 11$ & $0-7$ & 4.94 & 64.9 & 13.7 & 21.4 & $\mathrm{SCL}$ & 0.18 & 4.7 & \\
Moun & $\mathrm{A} 12$ & $7-21$ & 3.65 & 73.1 & 9.7 & 17.2 & $\mathrm{SL}$ & 0.12 & 4.0 & \\
tainous & $\mathrm{A} 3$ & $21-41$ & 2.61 & 59.1 & 17.9 & 23.0 & $\mathrm{SCL}$ & 0.09 & 4.2 & $\mathrm{~B}$ \\
area & (B) & $41-50$ & 1.84 & 73.7 & 8.2 & 18.1 & $\mathrm{SL}$ & 0.07 & 4.1 & \\
& $\mathrm{C}$ & $50-65+$ & 0.85 & 85.2 & 5.3 & 9.5 & $\mathrm{LS}$ & 0.03 & 4.2 & \\
\hline Sub & $\mathrm{A} 11$ & $0-7$ & 6.03 & 68.0 & 16.4 & 15.6 & $\mathrm{SL}$ & 0.19 & 4.5 & \\
moun & $\mathrm{A} 3$ & $7-23$ & 2.71 & 65.2 & 16.2 & 18.6 & $\mathrm{SL}$ & 0.07 & 4.0 & \\
tainous & (B) & $23-35$ & 1.41 & 65.4 & 21.8 & 12.8 & $\mathrm{SL}$ & 0.05 & 4.1 & $\mathrm{~B}$ \\
area & (B) & $35-80$ & 0.89 & 61.3 & 25.0 & 13.7 & $\mathrm{SL}$ & 0.05 & 4.5 & \\
& $\mathrm{C}$ & $80-110+$ & 0.62 & 71.7 & 15.7 & 12.6 & $\mathrm{SL}$ & 0.03 & 4.8 & \\
\hline
\end{tabular}

\subsection{Structural types}

Four main st. types were found. All st. types belong to site type B.

\subsubsection{Mountainous part of study area}

In this part, two st. types were found.

\subsubsection{St. type 1. Q. dalechampii-F. sylvatica stands}

In this type 5 sample plots were established. Most of the oak trees are 115-135 years old, except some trees which are younger (25-45 years old), whereas the age of the beech trees is between $40-60$ years.

This stage was initiated by stand destroying disturbances in which the most trees were killed (probably grazing was the agent which caused the disturbances). The disturbances were intense, extended in a relatively large area and acted for a long period of time. Only some oak trees and a few suppressed sparsely scattered beech trees survived. At first, gaps were colonized by oak which in that case acted as a pioneer species. Oak probably existed in the area (mixed with beech) mainly in, rather, sunny places and in bad site qualities. It is most probable that the oaks, that first colonized the gaps, came from trees (seeds) which had survived, from the disturbance, and had been removed, later, by forest commission cuttings. The 'late succession species' of F. sylvatica appeared later, after 70-90 years (the seeds come from the suppressed survivors).

The duration of beech invasion was about 20 years (in all sample plots of this stage). The younger oaks which have smaller dimensions than the others, were established in gaps created later by small disturbances (windfall or the death of a few trees or cuttings). 

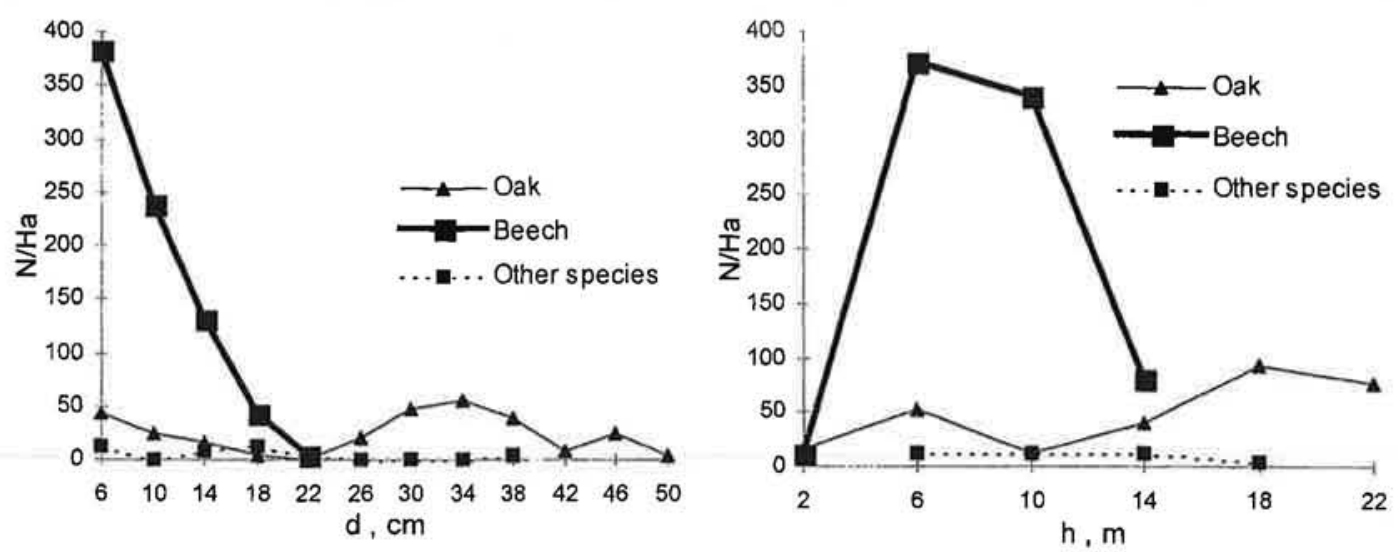

Figure 1. Structure analysis graph of diameter and height classes of st. type 1, in the mountainous part of the study area.

Table 2. Mean stand statistics for st. type 1, in the mountainous part of the study area

\begin{tabular}{c|cc|cc|c|c}
\hline Species & \multicolumn{2}{|c|}{ DBH } & \multicolumn{2}{c|}{ Height } & N/Ha & B. A. $\left(\mathrm{m}^{2} / \mathrm{ha}\right)$ \\
& Mean (cm) & St. Deviat. & Mean $(\mathrm{m})$ & St. Deviat. & & \\
Oak & 26.5 & 13.5 & 14.7 & 6.4 & 288 & $\mathbf{2 0 . 0}$ \\
Beech & 8.7 & 3.7 & 8.2 & 2.5 & 804 & 5.7 \\
Other species $^{\mathrm{a}}$ & 14.8 & 9.1 & 10.8 & 4.9 & 40 & 0.9 \\
\hline
\end{tabular}

a.The main species of the 'other species' component is Carpinus betulus. Also there are Fraxinus ornus and Populus tremula trees.

Today, regeneration appears in growing space released by forest commission cuttings. It consists mainly of beech seedlings and saplings and secondly of few oak seedlings and saplings found in, rather, sunny and dry microenvironments.

The mean st. type statistics are presented in table 2 and the bole distribution in diameter classes is given in figure 1. Even though beech trees are almost evenly aged, we observe a exponential distribution. This happens because of the site conditions which delayed the dimensions differentiation. The oak diameter distribution is analogous to the oak trees age structure. The older trees are in the larger classes, whereas the younger trees are located in the smaller classes. The diameter differences between the trees in the larger diameter classes are the result of growth differences among trees in the same age group. The tree height distribution (see fig. 1) shows an almost multistorey stand. Oak dominates in the upper storeys and beech in the lower storeys.

\subsubsection{St. type 2. F. sylvatica-Q. dalechampii stands}

In this type 5 sample plots were established. Most of the oak trees are 115-135 years old. However there are a few trees which are older and a few which are younger. The beech trees belong to two age groups. Although in the main group, the trees are 100-120 years old and some are older, in the second group, they are 20-50 years old. 
Ten. Stands in two areas in the Rhodope mountains of Xanthi region

According to our data, this stage was initiated by disturbances which were not so intense and did not affect a large area (illegal cuttings or windfalls, or a combination of both). The duration of these disturbances was not long either, but they destroyed almost all the trees (except for a few oak and beech trees) in an area of 600 to $1500 \mathrm{~m}^{2}$. The main characteristic of these gaps is that they were surrounded by groups of adult beech trees and few old oak trees (today some of these trees are over 160 years old).

There was an almost parallel invasion of beech and oak trees. In many cases, the area was refilled a) by beech and oak individuals growing from seeds which came from the survived trees and from seeds of surrounding adults $b$ ) by few sprout origin oak trees and c) by growth of survived beech and oak individuals. The oak and beech trees occupied all available growing space. The new beech trees (the younger age group) and the few young oak individuals were established afterwards in the growing space that was created by small disturbances (windfall, or death of one or few trees, cuttings etc.).

Today (as in st. type 1) regeneration appears in growing space released by forest commission cuttings. It consists mainly of beech seedlings and saplings and secondly of few oak seedlings and saplings found in, rather, sunny and dry microenvironments. There are also some Acer hyrcanum, Populus tremula and Carpinus betulus seedlings.

Figure 2 presents the bole distribution in diameter classes (see table 3 for the mean st. type statistics). Beech trees show different patterns in diameter distribution and age structure. As we have mentioned earlier, age structure has a discontinuous pattern. The continuous pattern of diameter distribution (see fig. 2) was affected by growth differences among trees in each age group. The oak diameter distribution shows an almost normal distribution between the diameter classes of $20-50 \mathrm{~cm}$. This distribution represents the age group of 115-135 years old. The younger trees appear in small diameter classes. The tree height distribution (see fig. 2) shows an almost multistorey stand. Beech dominates in all storeys.
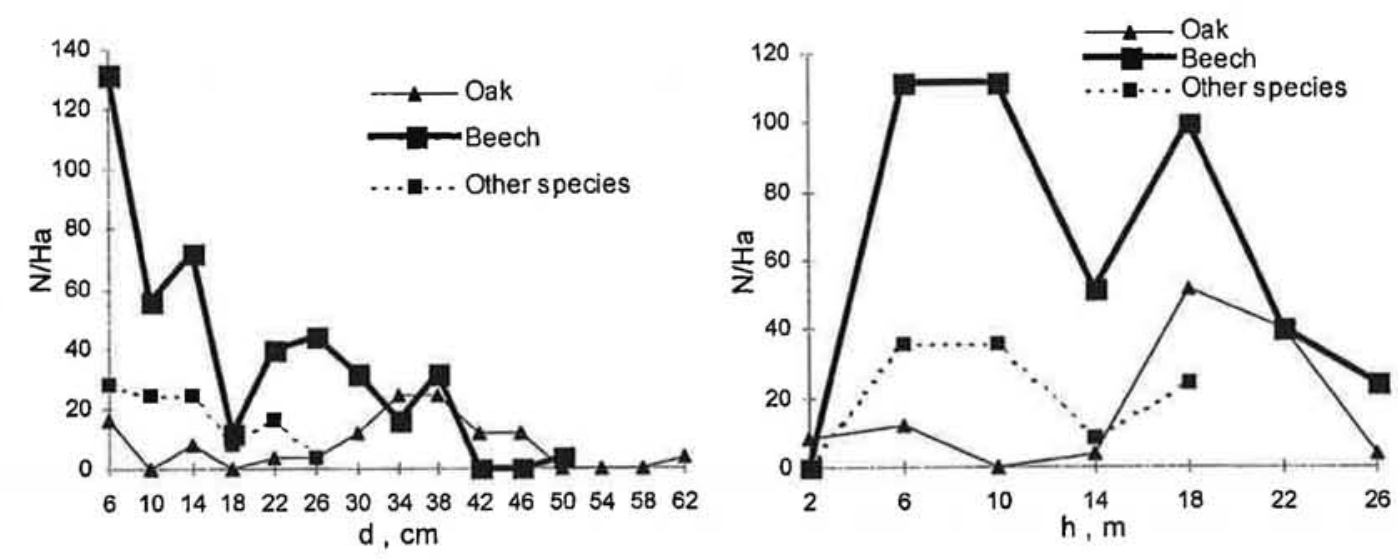

Figure 2. Structure analysis graph of diameter and height classes of st. type 2 , in the mountainous part of the study area.

b. The main species of the 'other species' component is Carpinus betulus. Also there are Betula pendula, Ostrya carpinifolia, Fraxinus ornus, Corylus avellana, Acer hyrcanum and Prunus mahaleb trees. 
Ten. Stands in two areas in the Rhodope mountains of Xanthi region

Table 3. Mean stand statistics for st. type 2, in the mountainous part of the study area

\begin{tabular}{|c|c|c|c|c|c|c|}
\hline Species & \multicolumn{2}{|c|}{ DBH } & \multicolumn{2}{|c|}{ Height } & \multirow[t]{2}{*}{$\mathrm{N} / \mathrm{Ha}$} & \multirow{2}{*}{$\begin{array}{c}\text { B. A. } \\
\left(\mathrm{m}^{2} / \mathrm{ha}\right)\end{array}$} \\
\hline & Mean $(\mathrm{cm}$ & St. Deviat. & Mean (m) & St. Deviat. & & \\
\hline Beech & 16.5 & 10.9 & 12.9 & 6.0 & 440 & 13.4 \\
\hline Oak & 31.2 & 13.8 & 16.9 & 6.0 & 120 & 10.8 \\
\hline Other species ${ }^{b}$ & 12.4 & 6.2 & 11.0 & 4.3 & 104 & 1.6 \\
\hline
\end{tabular}

\subsubsection{Submountainous part of study area}

In this part, two st. types were found.

\subsubsection{St. type 1. F. sylvatica-Q. dalechampii (two aged)stands}

In this type $\mathbf{5}$ sample plots were established. Beech is two aged. The majority of trees are $30-$ 50 years old, except a few individuals which are 65-75 years old. Almost the same age structure is found in oak. The only difference is that in oak case there is a number of sprout origin young trees.

Most of the beech trees are seed origin and most of the oak trees (especially the young trees) are sprout origin.

The stands of this st. type are located in the boundaries of the two species altidudinal distribution, nearby cultivated areas.

This st. type is the result of anthropogenic disturbances. Present human activities still affect stands structure.

According to our data (information which was taken from old residents of the nearby villages and age distribution of the trees) in the past, in these stands, there was a small number of beech and oak trees (old age group of trees), due to intense grazing and illegal cuttings, as a result of their vicinity to the residents fields. The years after, the pressure of human activities was reduced because of forest service protection and the fact that the residents of the area turned in other activities. This process resulted in the formation of the present structure of the stands.
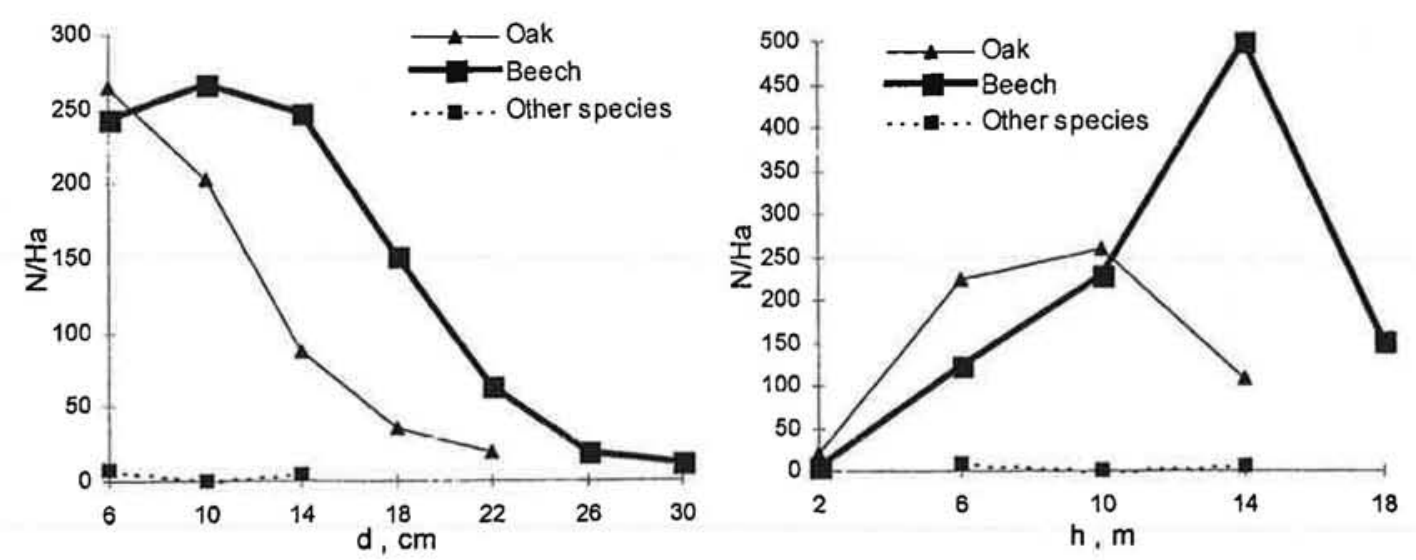

Figure 3. Structure analysis graph of diameter and height classes of st. type 1 , in the submountainous part of the study area. 
Ten. Stands in two areas in the Rhodope mountains of Xanthi region

Until today illegal cuttings form the species composition of the stands, due to the use of oak wood as firewood, the number of trees and the contribution of oak in the total basal area of stands is small. Also the sprout origin of young oak trees is the result of these illegal cuttings.

Table 4. Mean stand statistics for st. type 1, in the submountainous part of the study area

\begin{tabular}{c|cc|cc|c|c}
\hline Species & \multicolumn{2}{|c|}{ DBH } & \multicolumn{2}{c|}{ Height } & N/Ha & B. A. $\left(\mathrm{m}^{2} / \mathrm{ha}\right)$ \\
& Mean (cm) & St. Deviat. & Mean $(\mathrm{m})$ & St. Deviat. & & \\
Beech & 12.0 & 5.4 & 12.4 & 3.3 & 1008 & 13.7 \\
Oak & 9.1 & 4.2 & 8.8 & 2.8 & 612 & 4.8 \\
Other species & 7.7 & 4.6 & 8.0 & 4.0 & 12 & 0.1 \\
\hline
\end{tabular}

In the beech diameter distribution (fig. 3), trees of the older age group are represented by the diameter classes of 26 and $30 \mathrm{~cm}$, while the younger trees appear at the left of the distribution. The oak diameter distribution, at first sight, resembles to a distribution of a more or less even aged structure of a young stand. This is not true, at the right appear the older trees, the age group of 30-50 years old is represented by the diameter classes around the center of the distribution, whereas most of the young sprout origin trees are located in the class of $6 \mathrm{~cm}$.

The tree height distribution in height classes (see fig. 3) shows an almost multistorey stand with the maximum trees massing in the 10 and $14 \mathrm{~m}$ height classes. The upper storeys are dominated by beech trees, while the lower storeys are dominated by oak trees.

The mean st. type statistics are presented in table 4.

\subsubsection{St. type 2. F. sylvatica-Q. dalechampii (unevenly aged) stands}

In this type 8 sample plots of $500 \mathrm{~m}^{2}$ were established. In theze stands both beech and oak are unevenly aged. The older trees are over 130 years old.

The stands of this st. type are located in the boundaries of the two species altidudinal distribution. They are found either in cool north facing slopes, inside pure oak forests, and in south facing slopes, inside pure beech forests.

Most of the beech trees are seed origin and a great number of oak trees (especially the younger trees) are sprout origin.

There are not any signs of a major disturbance in the past, but the structure and composition of the stands were and still are formed by illegal cuttings in which the oak wood is preferred.

Regeneration appears in growing space released by forest commission cuttings. It consists both of beech and oak seedlings and saplings. In oak regeneration, which is found mostly in, rather, sunny and dry microenvironments, there are also stump sprouts and seedlings sprouts. Furthermore there are a few Fraxinus ornus, Sorbus torminalis and Corylus avellana seedlings.

The mean st. type statistics are presented in table 5 and the bole distribution in diameter classes is given in figure 4 . The beech diameter distribution is analogous to the beech trees age structure. The older trees are in the larger classes, whereas the younger trees are located in the smaller classes. Even though oak trees are unevenly aged its distribution resembles an almost normal distribution as a result of growth differences among trees with different age. 
The tree height distribution (see fig. 4) shows an almost multistorey stand. Beech dominates in all storeys.
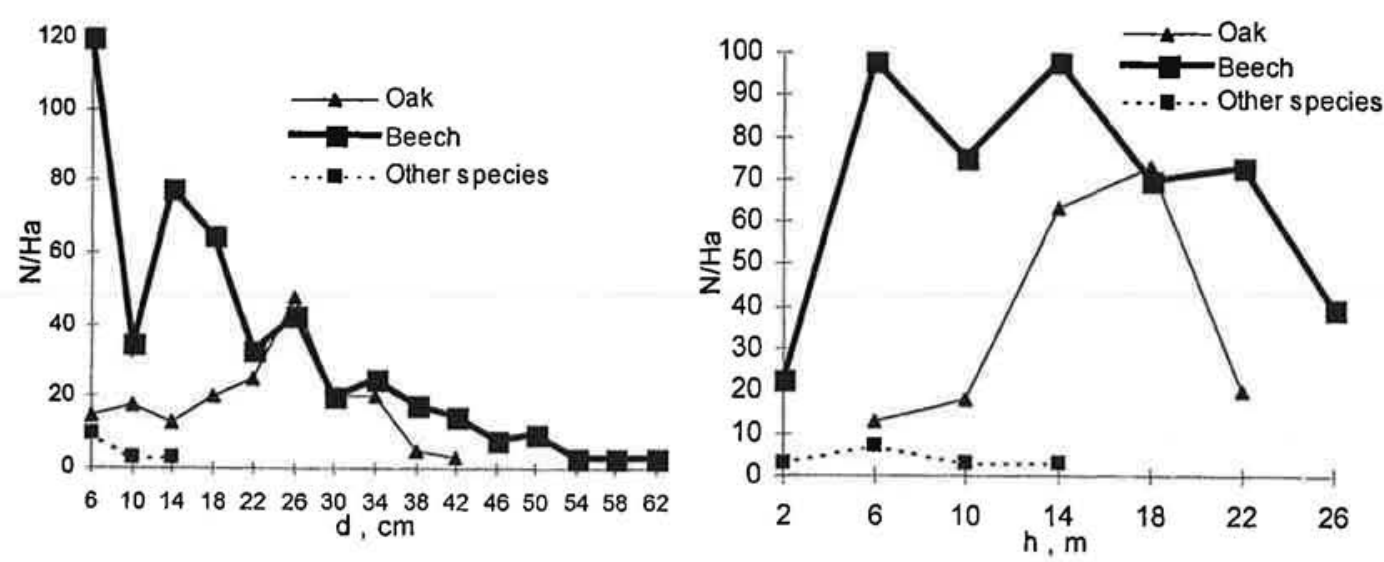

Figure 4. Structure analysis graph of diameter and height classes of st. type 2, in the submountainous part of the study area.

Table 5. Mean stand statistics for st. type 2, in the submountainous part of the study area

\begin{tabular}{c|cc|cc|c|c}
\hline Species & \multicolumn{2}{|c|}{ DBH } & \multicolumn{2}{c|}{ Height } & N/Ha & B. A. $\left(\mathrm{m}^{2} / \mathrm{ha}\right)$ \\
& Mean $(\mathrm{cm})$ & St. Deviat. & Mean $(\mathrm{m})$ & St. Deviat. & & \\
Beech & 18.7 & 12.7 & 13.8 & 6.8 & 475 & 19.0 \\
Oak & 22.0 & 8.8 & 15.2 & 4.1 & 185 & 8.2 \\
Other species & 7.7 & 2.8 & 7.3 & 3.7 & 15 & 0.1 \\
\hline
\end{tabular}

\subsection{Stem analysis}

The first couple of trees consists of a dominant oak and an adjacent, competing, dominant, beech tree. The trees were cut in a st. type 2, of the mountainous part of the study area plot. The oak tree is 126 years old and the beech tree is 108 years old (see table 6). In figures 5, 6 we observe that the oak tree showed an early culmination (peak) in the periodic annual height increment, having rather high values in current annual volume increment. It probably was a seedling sprout which arose just after the disturbance. On the contrary beech (which was established 18 years later) had a suppressed early height and volume growth because of intense competition from other trees. The years after, beech exhibited higher height increment than oak, however the shapes of their periodic annual height increment distribution were analogous leading to the conclusion that the abiotic conditions were the major factors which shaped the height growth of the two trees. In the last decades (after the first $80-85$ years of the beech tree life) beech has by far higher volume increment than oak, furthermore in the last 16 years it is taller than the oak tree. The dominance of beech will continue, in the future, as a result of its different growth ecology from oak (beech trees reach greater dimensions than oak trees) and of the fact that oak is in a rather extreme environment (high altitude) for the species. 
Table 6. The ages, heights and volumes of trees in the two competing couples

\begin{tabular}{cccccccccc}
\hline \multicolumn{1}{c}{ Couple 1. (mountainous part of the study area) } & \multicolumn{3}{c}{ Couple 2. (submountainous part of the study } \\
area)
\end{tabular}

a. $1000 \mathrm{dm}^{3}=1 \mathrm{~m}^{3}$

The second couple consists of a dominant oak and an adjacent, competing, dominant, beech tree too. The trees were cut in a st. type 2 , of the submountainous part of the study area plot.
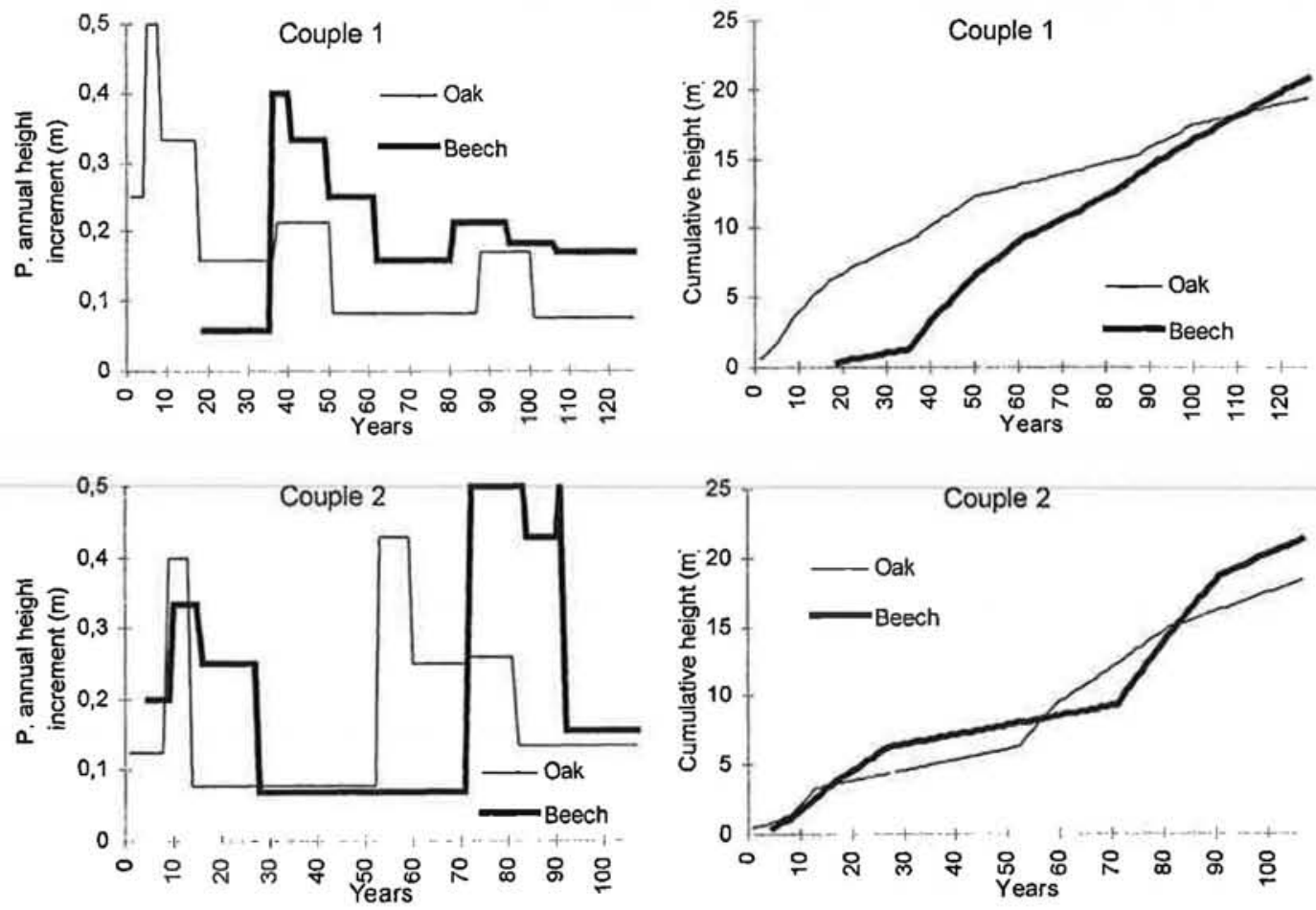

Figure 5. Periodic* annual height increment and cumulative curves in the two competing couples.

* The period is not constant. In order to calculate p. a. i., we divide the height differences between the sequential cross-sectional discs by their age differences. We have exact height differences between (almost all) the discs, but their age differences (period in our case) varies. 
Ten. Stands in two areas in the Rhodope mountains of Xanthi region
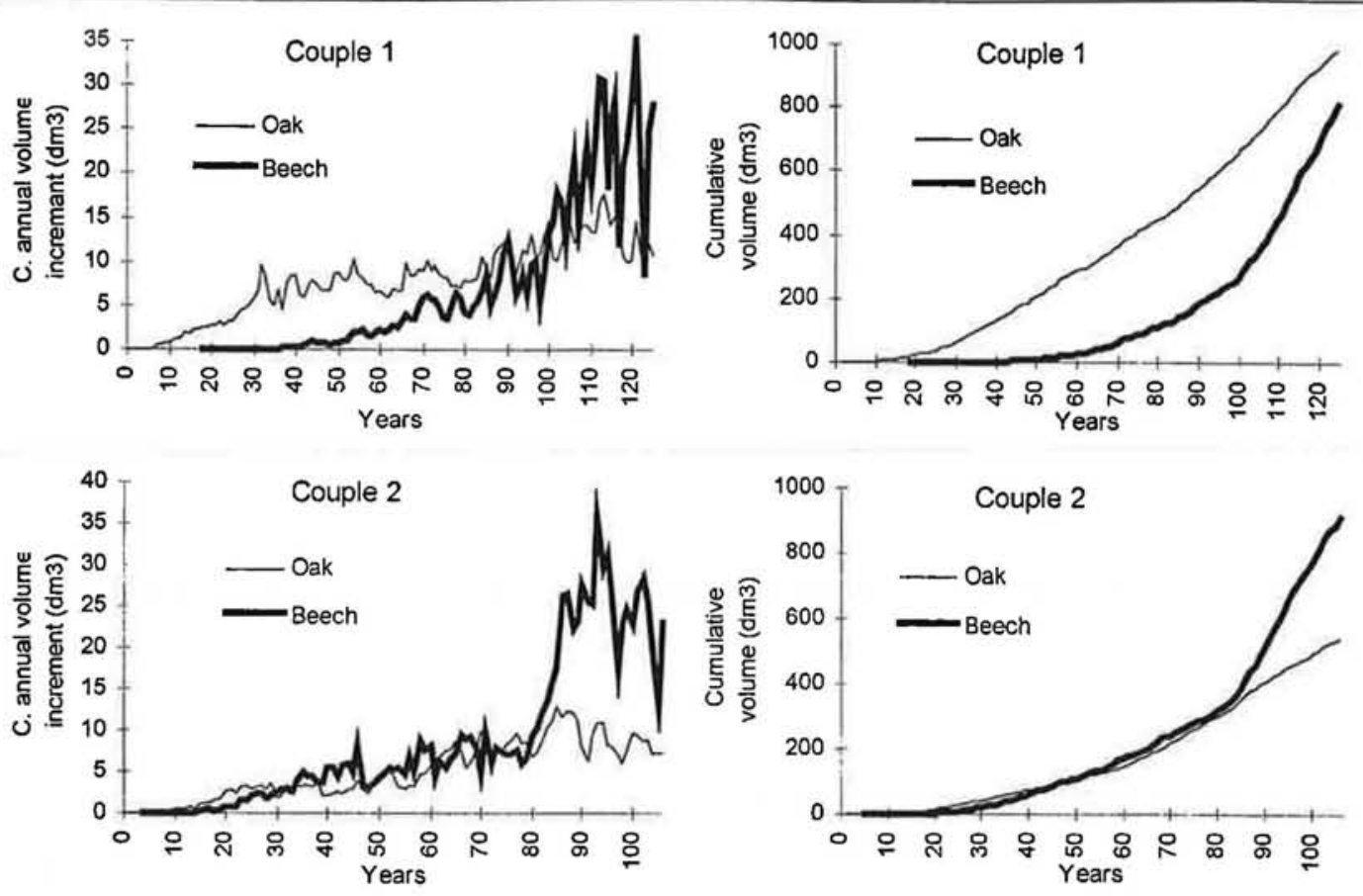

Figure 6. Current annual volume increment and cumulative curves in the two competing couples.

The oak tree is 107 years old and the beech tree is 103 years old (see table 6 ). In figure 5, we observe that there were periods of time where one tree gained an advantage over the other, as far as the periodical annual height increment is concerned. It is obvious that the abiotic conditions were not the critical factors that shaped the height growth patterns of the two trees. It is most probable that in concrete periods of time, one tree was more or less <<suppressed >> by the other in combination with the competition of other trees. This <<suppression>> was not severe to give a volume advantage in one of the two trees. Another possible reason for the suppressed height growth (in some years) of the two trees is probable injuries from illegal cuttings. After the first 70 years of the oak tree life the beech tree showed greater values of height growth than oak.

Besides their periodical annual height increment patterns, the two trees had almost the same volume and height in the first $80-85$ years of the oak tree life (figures 5,6). Afterwards the beech tree showed by far greater rates of volume growth than oak. This dominance of beech will probably continue, in the future, as a result of its different growth ecology from oak.

\section{Discussion}

Structures and development patterns of beech-oak mixed stands in the two parts of our study area, in Rhodope mountains, were quite different.

In the mountainous part of the study area, natural and anthropogenic disturbances form the initiation, development and structure of beech-oak stands. Our stands are located in an broad area, where forest stands development, composition and structures were determined by disturbances with varying characteristics. 
In nearby areas, with higher elevations, Milios (2000a) found that the population structures, the regeneration and development patterns of Pinus sylvestris-Fagus sylvatica stands were strongly influenced by human and natural disturbances and species 'life history characteristics'. Disturbances having the same characteristics with that which initiated the pine-beech stands are responsible for the initiation of beech-oak stands. In particular intense disturbances, extended in a relatively large area, that acted for a long period of time, led to the formation of pine-beech stands in which the upper storey consists of pine and the lower storey consists of beech (Milios 2000a). In our case the stands of st. type 1 were initiated by the same kind of disturbances. Furthermore, disturbances (with small duration) which were not so intense and did not affect a large area, but destroyed almost all the trees in an area of 600 to $1500 \mathrm{~m}^{2}$, are responsible for the creation of st. type 2 stands. In the same way, analogous disturbances led to the formation of gaps in which an almost parallel invasion of pine and beech trees took place, which later had almost the same growth rates (Milios 2000a).

According to Oliver and Larson (1996) 'subtle variation in disturbances and other events during the initiation of a stand can determine which species first occupy the growing space' . In the oak-beech stands case, the fact that a number of oak trees survived after the disturbance allowed the oak to act as a pioneer species. Otherwise a species having heavy seeds, such as oak, could never colonize a relatively large area in a rather short time.

Apart from what is mentioned above, landscape topography, which inhibited the dispersion of pine seeds, in combination with the local climate which is warmer than that of adjacent areas (south-facing slopes prevail in our stands) influenced the succession pathways in the area. Furthermore Milios et al. (2001) refer that, in areas with slightly lower altitude, located at the north of our study area, Populus tremula was the major pioneer species of the community.

Development patterns were also influenced by the species biology. According to Connell (1989) after the creation of a gap, some of the damaged remnants of the trees begin to resprout. The same process appears with oak sprouts in our st. type 2 stands. Apparently this did not happen with pine in the case of beech pine mixed stands. Another difference between the development of these two mixtures of beech in the area, resulting, possibly, from biology and architecture of the associated species, is the different duration of beech invasion under pine and oak in mixed (of these two species) with beech stands, resulted from intense disturbances in site type $B$. The duration of beech invasion under pine canopy was about 30 years, while the invasion under oak lasted 20 years. One of the possible explanations, is that under oak, which is denser than pine crown, and is a site sensitive (compared with pine for that site type) species, the available growing space for beech invasion, was smaller than in the pine case. As a result the period of beech invasion under oak was smaller.

Barring another disturbance and a significant change in climate, an almost total domination of the 'late successional species' of beech will be established. The presence of oak individuals or small groups, will be localized in sunny and dry places.

On the other hand, even though only one of the two st. types found in the submountanous part of the study area was initiated by (anthropogenic) disturbances, the structure and composition of both st. types stands were and still are formed by illegal cuttings in which the oak wood is preferred. The same process took place in the Ostya carpinifolia stands in the western part of Nestos valley (Milios 2000b). In that case 'In the last decades the pressure of illegal cuttings has 
been reduced and the social conditions have changed, as a result Quercus sp. began to reclaim the available growing space'. On the contrary in the submountainous part of our study area there is a larger (than in the previous case) population, having a traditional way of life, as a result oak wood is still used as firewood. The beech-oak mixture in this part of the study area is localized in areas where the coexistence of two species is feasible without the disturbance mediation since their abiotic requirements are met.

According to Bartelink (1999) 'the fact that in a forest stand, a tree's rate of success in obtaining scarce resources will be depended on tree dimensions and stand structure, in combination with the high diversity of competitive interactions, implies that the individual tree status and growing conditions have been much more important when predicting future stand dynamics'. Furthermore Larson (1992) mentions that a small difference in age and spatial relationships between individuals in a stand can be a factor which determines the dominance between species. In both competing couples, oak is (few or several years) older than beech. This difference probably allowed oak trees to compete, or even dominate (as far as height is concerned), the adjacent beech individuals for many decades. Otherwise, if beech preceded oak, the moderately shade tolerant oak trees would possibly not have been able to compete, so successfully, against older and taller individuals which belong to the shade tolerant 'late successional' species of beech. In both cases, the beech trees, after the first 80-85 years of their life, showed by far higher volume growth rates than the adjusted competitive oak trees which in combination with the trees height growth patterns implies, that in the future, a total domination of beech trees (in the two couples) will be observed.

Forest practice must preserve the mixture of beech and oak in the mountainous part of the study area and enhance the presence of oak component in the submountainous part of the study area stands, in order to maintain the diversity of these stands and avoid the disadvantages of a homogenous forest. Furthermore biological diversity is one of "the best tools to mediate an orderly transition of community types" (Perry 1994), if the predicted increase in the average global temperatures comes true. In that case, the zones of vegetation in Rhodope mountains are expected to shift upward from a few to several hundreds meters, resulting in the replacement of beech by oak in many locations. The presence of beech-oak mixtures will facilitate this transition. Perry et al. (1990) mention that the transition from one community type to another will be facilitated as long as there is sufficient overlap between old residents and migrants. According to Perry (1994) 'perhaps the most important task facing foresters during the twenty-first century will be to facilitate the orderly transition from one forest type to another'.

In our stands, foresters must use the suitable microenvironment and sites for each of the two species regeneration, but in the case of mixed regeneration an age advantage in oak young plants must be given.

\section{Conclusions}

In the mountainous part of the study area, natural and anthropogenic disturbances form the initiation, development and structure of beech-oak stands. However the fact that a number of oak trees survived after the disturbance in combination with landscape topography, which inhibited the dispersion of pine seeds, the species biology and the local climate, which is warmer 
Ten. Stands in two areas in the Rhodope mountains of Xanthi region

than that of adjacent areas, influenced the succession pathways in the area and allowed oak to act as a pioneer species. Barring another disturbance and a significant change in climate, an almost total domination of beech will be established. The presence of oak individuals or small groups, will be localized in sunny and dry places.

Even though only one of the two st. types found in the submountainous part of the study area was initiated by (anthropogenic) disturbances, the structure and composition of both st. types stands were and still are formed by illegal cuttings in which the oak wood is preferred. The beech-oak stands are localized in areas where the coexistence of two species is feasible without the disturbance mediation since their abiotic requirements are met.

In both competing couples, the age difference, between the trees, probably allowed oak trees to compete, or even dominate (as far as height is concerned), the adjacent beech individuals for many decades. In both cases, the beech trees, after the first $80-85$ years of their life, showed by far higher volume growth rates than the adjacent competitive oak trees which in combination with the trees height growth patterns implies, that in the future, a total domination of beech trees (in the two couples) will be observed.

Forest practice must preserve the mixture of beech and oak in the mountainous part of the study area and enhance the presence of oak component in the submountainous part of the study area stands, in order to maintain the diversity of these stands, to avoid the disadvantages of a homogenous forest and to mediate an orderly transition of community types, if the predicted increase in the average global temperatures comes true.

\section{References}

Alifragis, D.A. \& Papamichos, N.T. (1995). Description - sampling - laboratory analysis of forest soils and plant tissues (in Greek). Thessaloniki, $181 \mathrm{p}$.

Bartelink, H.H. (1999). Growth and management of mixed-species stands. In: Olsthoorn A.F.M., Bartelink H.H., Gardiner J.J., Pretzsch H., Hekhuis H.J. and Frank A. (Eds). Management of mixed-species forest: silviculture and economics. IBN Scientific Contribution 15. DLO Institute for Forestry and Nature Research (IBN-DLO), Wageningen , 186-190.

Connell, J.H. (1989). Some processes affecting the species composition in forest gaps. Ecology, 70(3), 1989, 560-562.

Dafis, S. (1986). Forest Ecology (in Greek), Giahoudi Giapouli, Thessaloniki, 443 p.

Dimadis, E. \& Zachos, S. (1986). Geological map of Rhodope massif, 1:200.000.

Fortin, R. \& Labranche, M. (1996). XLSTEM ${ }^{T M}$ V.1.1. Users guide, Stem analysis software module for Microsoft excel 5.0., Regent instruments Inc. Canada, $14 \mathrm{p}$.

Husch, B., Miller, C.I. \& Beers, T.W. (1982). Forest Mensuration. John Willey \& Sons, Inc., $402 \mathrm{p}$.

Larson, B.C. (1992). Pathways of development in mixed-species stands. In : Ketly, M.J., B.C. Larson and C.D. Oliver (Eds.) The ecology and silviculture of mixed - species forests. Kluwer Academic Publishers, Dordrecht, 3-10.

Matis, K.I. (1989). Forest Biometry II (in Greek), Dendrometry, Thessaloniki, 451 p. 
Ten. Stands in two areas in the Rhodope mountains of Xanthi region

Milios, E., Aslanidou, M., Pipinis, E., Ranis, G. \& Berberidis, T. (2001). Dynamics of Populus tremula L. stands in central Rhodope in the region of Xanthi. Accepted for publication in Sci. Ann. Of Agric. For. Sch., Thessaloniki.

Milios, E. (2000a). Dynamics and development patterns of Pinus sylvestris L.-Fagus sylvatica L. stands in central Rhodope. Silva Gandavensis, no 65, 154-172.

Milios, E. (2000b). Structure and development patterns of the Ostrya carpinifolia pure and mixed stands in the western part of Nestos Valley. Silva Gandavensis, no 65, 128-153.

Oliver, C.D. \& Larson, B.C. (1996). Forest Stand Dynamics, John Wiley \& Sons, Inc. 520 p.

Paramichos, N.T. (1985). Forest soils (in Greek). Thessaloniki, 384 p.

Perry, D.A., Borchers, J.G. \& Amaranthus, M.P. (1990). Species migrations and ecosystems stability during climate change: the belowground connection. Conserv. Biol. 4, 266-274.

Perry, D.A. (1994). Forest Ecosystems. The Johns Hopkins University Press Baltomore and London, $649 \mathrm{p}$.

Philip, M.S. (1994). Measuring Trees and Forests. University Press, Cambridge UK, 310 p.

Smiris (1991). Silviculture research of Chestnut forests, Sci. Ann. Of Agric. For Sch., Thessaloniki, 15, 411-427.

Smiris, P., Maris, F. \& Stamou, N. (1998). Structure and stem analysis of Pinus halepensis Mill forests in the Kassadra Peninsula-Chalkidiki. Silva Gandavensis, no 63, 63-83.

Smith, D.M., Larson, B.C., Kelty, M.J. \& Ashton, P. Mark S. (1997). The practice of silviculture. Applied Forest Ecology. John Willey \& Sons, Inc., New York, 537 p.

Smith, R.L. (1992). Elements of Ecology. Harper Collins Publishers Inc., 617 p.

Tsiontsis, A. \& Elias, K. (1996a). Climatological data, 1978-1990. Forest meteorological station of Livathitis in Xanthi region (in Greek).

Tsiontsis, A. \& Elias, K. (1996b). Climatological data, 1978-1995. Forest meteorological station of Echinos in Xanthi region (in Greek).

Tsitsoni, T. (1997). Conditions determining natural regeneration after wildfires in the Pinus halepensis (Miller, 1768) forests of Kassandra Peninsula (North Greece). Forest Ecology and Management, 92, 1997, 199-208.

Zingg, A. (1984). Top Heights in Mixed Stands-their Definition and Calculation. In: Proceedings from the Symposium of the IUFRO Working Groups S4.01-03 and S4.01-04. Mixed Stands: Research Plots-Measurements and Results-Models. Lousa/Coimbra Portugal, 67-80. 